\title{
Seasonal dynamies of fish assemblages in an intertidal mudflat of Indian Sundarbans
}

\author{
ATREYEE CHAUDHURI, SUDESHNA MUKHERJEE and SUMIT HOMECHAUDHURI \\ Aquatic Bioresource Research Laboratory, Department of Zoology, University of Calcutta, 35 Ballygunge Circular Road,
} Kolkata 700019, India. E-mail: sumithomechaudhuri@gmail.com; sumithomec@yahoo.com

\begin{abstract}
SUMMARY: In the present study, the seasonal and inter-annual fish assemblage structure of intertidal mudflats of Indian Sundarbans was analysed during tidal cycles. A total of 31 fish species belonging to 22 families and 9 orders were collected during high tide, whereas only 12 were recorded during low tide. Fish assemblage descriptions were based on several community descriptors, namely diversity $\left(\mathrm{H}^{\prime}\right)$, species richness $(\mathrm{S})$, species dominance $(\mathrm{D})$, and species evenness (J) and on an ecological guild classification. A canonical correspondence analysis (CCA) was performed to evaluate the relationship between estuarine habitat and fish assemblages in the mudflat habitat during inundated and exposed conditions. All the diversity indices showed marked seasonal and inter-annual variations. Temporal variations were also found in fish assemblage structure in both tidal conditions. Estuarine species were the most important ecological guild of the mudflats during both high and low tides. Of all the abiotic variables examined, CCA showed that salinity, $\mathrm{pH}$ and nutrients were the most important influencing fish assemblage during high tide. Total dissolved solids, water temperature and salinity were significant during low tide. Considering the importance of mudflats in supporting fish diversity, the present study emphasizes the increased efforts for conservation of this habitat in the Indian Sundarbans.
\end{abstract}

Keywords: ichthyofaunal diversity, seasonal variation, tidal variation, mudflats, Bray-Curtis similarity, CCA.

RESUMEN: DinÁMICA ESTACIONAL DE COMUNIDADES DE PECES EN UNA MARISMA INTERMAREAL DE SundARBANS INDIO. En el presente estudio, la estructura estacional e interanual de comunidades de peces en el intermareal fangoso de Sundarbans se analizó durante ciclos de marea. 31 especies pertenecientes a 22 familias y 9 órdenes fueron recogidas durante la marea alta, mientras que sólo 12 se registraron durante la marea baja. Las comunidades se describieron varios descriptores: diversidad $\left(\mathrm{H}^{\prime}\right)$, riqueza de especies $(\mathrm{S})$, dominancia de especies (D) y uniformidad de especies (J) y una clasificación ecológica de comunidad. Se realizó un análisis de correspondencia canónico (CCA) para evaluar la relación entre hábitat estuárico y comunidades de peces durante condiciones inundadas y expuestas. Todos los índices de diversidad mostraron marcadas diferencias estacionales e interanuales. También se encontraron variaciones temporales en la estructura del conjunto de peces en tanto las condiciones de la marea. Especies estuarinas (ES) fue el grupo ecológico más importante de las marismas de Sundarbans tanto durante la marea alta como en la baja.

Palabras clave: diversidad íctica, variación estacional, variación de marea, marismas, similitud de Bray-Curtis, CCA.

\section{INTRODUCTION}

Estuaries and coastal lagoons show high levels of habitat heterogeneity and support a large fish production (Elliott and Hemingway 2002). Estuarine fish assemblages change significantly in relation to habitat characteristics and in particular to the degree of habitat complexity (Sogard and Able 1991, Connolly 1994, West and King 1996, Jenkins and Wheatley 1998, Paterson and Whitfield 2000).
Mudflats are a dominant habitat in many estuaries, often covering a considerable part of the total estuarine area. This particular type of habitat has been recognized to be of key importance for the estuarine food web due to its high productivity when compared with subtidal areas (Elliott and Dewailly 1995). Mudflats are structurally less complex than mangroves, but they contain great abundance and diversity of invertebrates and are periodically immersed and emerged in each tidal cycle. They are therefore only available to nekton during tidal 
inundation, which implies tidal migrations to use this habitat (Nagelkerken and van der Velde 2002, Pihl and Wennhage 2002, Weerts and Cyrus 2002, Mumby et al. 2004, Castillo-Rivera et al. 2010). However, unlike estuarine salt marshes, which have long been considered highly productive habitats and have been thoroughly studied (Cattrijsse et al. 1997, Halpin 2000, Hampel et al. 2003), mudflats have only recently become an object of study (Morrison et al. 2002, Melville and Connolly 2005, Dolbeth et al. 2007, Nip and Wong 2010).

Besides the differences in fish assemblages associated with the various habitat types, ichthyofaunal compositions and structure can also undergo consistent cyclical and temporal changes within habitats. Seasonal shifts in fish communities are common, as a result of sequential immigration and emigration of certain fish species (Hyndes et al. 1999, Thiel and Potter 2001). Tidal shifts in fish assemblages have also been reported by several authors (Sogard et al. 1989, Rountree and Able 1993, Gray et al. 1998, Griffiths 2001, Methven et al. 2001, Morrison et al. 2002, Guest et al. 2003). Several environmental factors, in addition to habitat availability, contribute to fish assemblage structure in different spatial and temporal scales (Thiel et al. 1995, Methven et al. 2001).

The Sunderbans mudflats (Banerjee 1998, Bose 2004) are found at the estuary and on the deltaic islands where velocity of river and tidal current is low. The flats are exposed at low tides and submerged at high tides, thus being changed morphologically even in one tidal cycle. The interior parts of the mudflats are a magnificent home of luxuriant mangroves. The Sunderbans mudflats control the food chain in the estuarine ecosystem.

This study aims (1) to characterize the nekton assemblage of the mudflat habitats of the Sundarbans estuary, (2) to assess the effect of seasonal and interannual variations in fish assemblage structure in two tidal phases, and (3) to relate environmental variables with fish assemblages. These should provide a better understanding of the role of the strait in supporting coastal fish communities.

\section{MATERIALS AND METHODS}

\section{Study area}

The total area of the Sundarban region in India is $9630 \mathrm{~km}^{2}$, which constitutes the Sundarban Biosphere Reserve between $21^{\circ} 40^{\prime} 04^{\prime \prime} \mathrm{N}$ and $22^{\circ} 09^{\prime} 21^{\prime \prime} \mathrm{N}$ and between $88^{\circ} 01^{\prime} 56^{\prime \prime} \mathrm{E}$ and $89^{\circ} 06^{\prime} 01^{\prime \prime} \mathrm{E}$. The landscape is characterized by a web of tidal water systems. The mean depth of the estuary is $5 \mathrm{~m}$ and the maximum depth is $40 \mathrm{~m}$ near the mouth of the estuary. The river flow varies both seasonally and inter-annually, with a mean discharge of $400 \mathrm{~m}^{3} \mathrm{~s}^{-1}$ (Bettencourt and Ramos, 2003).

Twelve study sites with similar physical features (composed predominantly of well-packed soft mud) were selected randomly along a $10 \mathrm{~km}$ stretch of the

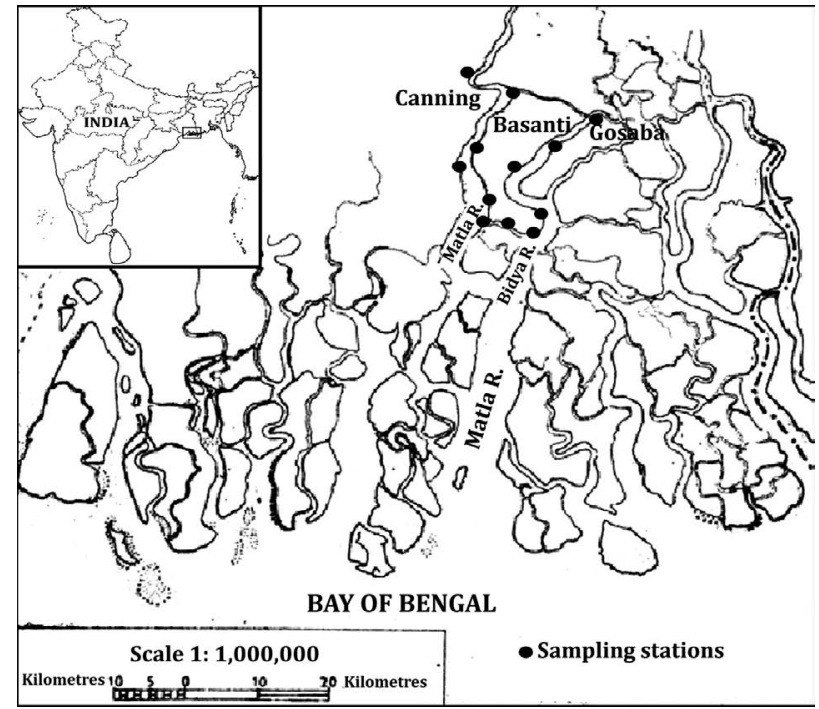

FIG. 1. - Map of the Indian Sundarbans showing the locations of study sites and sampling stations.

River Matla, the River Bidya, the Boro Hero bhanga rivulet and their adjacent mudflats in the Indian Sundarban $\left(22^{\circ} 01^{\prime} \mathrm{N}, 88^{\circ} 40^{\prime} \mathrm{E}\right)$ (Fig. 1). The sampling covered a total area of $35 \mathrm{~km}^{2}$ with a mean depth of $2.15 \pm 0.76 \mathrm{~m}$ and a tidal range of $3 \mathrm{~m}$ per $6 \mathrm{~h}$.

\section{Sampling and environmental data}

Sampling was conducted seasonally (pre-monsoon: February-May, monsoon: June-September and post monsoon: October-January) between October 2008 and September 2011. Fish sampling was performed during high tide with a gill net of $20 \mathrm{~m}$ length, with $1 \mathrm{~cm}$ spacing between adjacent knots. The nets were placed at the onset of high tide and kept for approximately $6 \mathrm{~h}$ in order to ensure maximum fish catch per unit effort during high tide. Sixteen nettings were undertaken at each site of this estuary per season, i.e. four nettings per month at each site. Four nettings were pooled together and represented here as single abundance data for each site per month. The replicate sites were sampled simultaneously and for the same tenure to minimize the sampling errors (single abundance data from each site, i.e. 12 replicates per month, 48 replicates per season and 144 replicates per year). During low tide a few $100 \mathrm{~m}$ transects were established at each study site to study the amphibious fishes. Along the transect $2 \times 2$ m quadrates constructed from nylon ropes and bamboo sticks were temporarily established at intervals of 8 m (approx. 10 quadrates per transect). Hand nets (dot net) were also used for sampling tidal pools during low tide. The specimens were retrieved from the net and identified, and species abundance was recorded to investigate species assemblages. Individuals representing each fish species were preserved in 5\% formalin and the live fishes were measured for total length $\left(\mathrm{L}_{\mathrm{T}}\right.$, $\mathrm{cm})$ and released. Fish specimens were identified to the lowest taxonomic level following the existing literature 
(Shaw and Shebbeare 1937, Day 1958, Talwar and Jhingran 1991).

At each sampling station, prior to netting hydrological parameters (water temperature, $\mathrm{pH}$, total dissolved solids, salinity, inorganic phosphate, nitrate nitrogen, nitrite nitrogen and reactive silicate) were recorded during high tide following Strickland and Parsons (1972), Grasshoff et al. (1983) and Grasshoff (1983) and soil parameters (soil moisture, soil $\mathrm{pH}$, soil organic matter and soil organic carbon) were recorded during low tide following Brower et al. (1998).

\section{Data analyses}

Total fish abundance (number of individuals) was calculated for each season in each year. Species richness (S) (Margalef 1957), Pielou evenness (J) (Pielou 1969), species dominance (D) (Berger and Parker 1970) and the Shannon-Wiener diversity index $\left(\mathrm{H}^{\prime}\right)$ (Shannon and Wiener 1949) were calculated for high-tide and low-tide conditions in three seasons in each year. Cluster analysis with the Bray-Curtis similarity measure was used to determine similarity between seasonal nekton assemblages for each year during high tide and low tide on the basis of species abundance data using PRIMER 5 software. Results were displayed using non-metric multidimensional scaling plots, on which percentage similarity levels were assigned based on group-average linkage (Horinouchi 2009). The abundance data were square-root transformed when necessary. To determine whether or not major shifts in community structure had occurred between groups of seasons and between years, a non-parametric, permutation-based two-way analysis of similarity (ANOSIM, Clarke, 1993) was performed. Where appropriate, R-statistic values for pair-wise comparisons provide by ANOSIM was used to determine the dissimilarity between groups. Values close to 1 indicate very different composition, while values near zero show little difference. ANOSIM was used to test the null hypothesis that within seasons no changes in community structure were observed between years, and secondly to check that within years no changes in community struc- ture were observed between seasons separately for hightide and low-tide conditions. Species were classified by functional groups according to Franco et al. (2008) and each species was assigned to an ecological guild. The ecological guilds contained estuarine species (ES), marine migrants $(\mathrm{MM})$, freshwater species $(\mathrm{F})$, anadromous species (A) and catadromous species (C). Ecological guilds were analysed by both number of species and number of individuals within each guild. The percentage contribution of each functional category to the total species richness and species abundance was calculated for two tidal conditions in each season and in each year, and compared to assess the prevailing function of each system during the time period of the present study. Analysis of variance (ANOVA) was performed on hydrological parameters, diversity indices and ecological guilds. As the study focused mostly on the temporal factors (seasons and years) in two tidal phases, one-way ANOVA (Zar 1999) was carried out separately with seasons (three levels: pre-monsoon, monsoon and post monsoon) and years (year 1, year 2 and year 3) as factors. A Duncan test was used for post hoc comparisons after ANOVA. Statistical analyses were carried out by means of SPSS (Statistical Package for Social Sciences, version 17.0 Norušis 2000). Finally canonical correspondence analysis (CCA) (Ter Braak 1988; McGarigal et al. 2000) was performed in order to elucidate the possible relationships between biological assemblages of species and the hydrological variables during two tidal phases. The seasonal samplings from all the study sites in three years were included in the analysis. Rare species in the fish species matrix were downweighted following the CANOCO procedure in order to prevent them from having an excessive influence on the ordination. This analysis was carried out using CANOCO (ver. 4.5) software.

\section{RESULTS}

Seasonal trends of water and soil parameters in three respective years are given in Table 1. All the parameters except soil organic carbon and soil organic matter varied significantly $(p<0.01)$ between seasons

TABLE 1. - Water and soil parameters (abbreviations are in parenthesis) of studied mudflats of the Indian Sundarbans. Sal, salinity (PSU); W tm, water temperature $\left({ }^{\circ} \mathrm{C}\right)$; TDS, total dissolved solids $\left(\mathrm{gL}^{-1}\right)$; I Phs, inorganic phosphate $\left(\mu \mathrm{ML}^{-1}\right)$; Na N, nitrate- $\mathrm{N}\left(\mu \mathrm{ML}^{-1}\right)$; Ni N, nitrite-N $\left(\mu \mathrm{ML}^{-1}\right)$; Sil, reactive silicate $\left(\mu \mathrm{ML}^{-1}\right)$; S OC, soil organic carbon (\%); S OM, soil organic matter $(\%)$; S Mo, soil moisture $(\%) ; \mathrm{S} \mathrm{pH}$, soil pH.

\begin{tabular}{|c|c|c|c|c|c|c|c|c|c|}
\hline Hydrolo & Year 1 & $\begin{array}{c}\text { Pre-monsoon } \\
\text { Year } 2\end{array}$ & Year 3 & Year 1 & $\begin{array}{l}\text { Monsoon } \\
\text { Year } 2\end{array}$ & Year 3 & \multicolumn{3}{|c|}{$\begin{array}{l}\text { Post-monsoon } \\
\text { Year } 2\end{array}$} \\
\hline 1 & $26.74^{\mathrm{a}} \pm 0.06$ & $31.03^{\mathrm{b}} \pm 0.56$ & $31.05^{\mathrm{b}} \pm$ & 33 & & 10. & $2+.00$ & 19.9 & 17.3 \\
\hline $\mathrm{W}$ tn & $31.56^{\mathrm{a}} \pm 0.11$ & $34.81^{\mathrm{b}}=$ & $34.21^{\mathrm{b}}$ & 28 & 29.6 & 28. & 24.81 & 27.7 & \\
\hline pH & $7.98^{\mathrm{a}} \pm 0.07$ & $7.14^{\mathrm{b}} \pm 0.02$ & $7.08^{\mathrm{b}}$ & .02 & $6.83^{\mathrm{d}} \pm 0.02$ & $7.06^{\mathrm{b}} \pm 0.04$ & $7.00^{\mathrm{h}} \pm 0.02$ & $6.99^{\mathrm{h}} \pm 0.02$ & 0.03 \\
\hline TDS & $2.53^{\mathrm{c}} \pm 0.07$ & $3.16^{\mathrm{a}} \pm 0.02$ & & & $\mathrm{~d}_{ \pm 0} 0.03$ & $1.96^{b} \pm c$ & $1.35^{\mathrm{h}} \pm 0.04$ & \pm 0.12 & $=0.13$ \\
\hline I Phs & $0.14^{\mathrm{a}} \pm 0.03$ & 0.79 & 02 & 12 & .51 & & \pm 0.01 & 2.3 & $2.15^{\mathrm{h}} \pm 0.19$ \\
\hline $\mathrm{NaN}$ & 0.95 & & $2.24^{\mathrm{c}} \mathrm{r}-\mathrm{c}$ & 55 & 3.1 & 6.2 & $2.30^{\mathrm{d}} \pm 0$ & 0.05 & $6.98^{\mathrm{i}} \pm 0.05$ \\
\hline $\mathrm{Ni} /$ & & & & & & & 0.06 & 0.79 & 2.26 \\
\hline Sil & 8.05 & $7.90^{\mathrm{a}} \pm 09$ & $12.95^{\mathrm{b}} \pm 2.15$ & $16.70^{\mathrm{d}} \pm 0.47$ & $17.80^{\mathrm{d}} \pm 0.51$ & $17.97^{\mathrm{d}} \pm 0.93$ & $7.76^{\mathrm{a}} \pm 0.04$ & $7.71^{\mathrm{a}} \pm 0.04$ & $18.08^{\mathrm{d}} \pm 0.07$ \\
\hline $\mathrm{S}$ OC & $0.91^{\mathrm{a}} \pm 0.04$ & $0.91^{\mathrm{a}} \pm 0.04$ & $0.91^{\mathrm{a}} \pm 0.04$ & & & & $0.90^{\mathrm{a}} \pm 0.03$ & $0.90^{\mathrm{a}} \pm 0.03$ & $0.90^{\mathrm{a}} \pm 0.03$ \\
\hline & & & & & & & 05 & 1.5 & 1.5 \\
\hline S Mo & $54.81^{\mathrm{a}} \pm 2.06$ & $54.8^{\mathrm{a}} \pm 2.06$ & $55.70^{\mathrm{a}} \pm 2.06$ & $55.70^{\mathrm{a}} \pm 1.22$ & $55.70^{\mathrm{a}} \pm 1.22$ & $55.70^{\mathrm{a}} \pm 1.22$ & $44.79 \mathrm{~g} \pm 1.17$ & 44.79 & $44.79 \mathrm{~g}_{ \pm}+1.17$ \\
\hline $\mathrm{SpH}$ & $7.40^{\mathrm{a}} \pm 0.06$ & $7.40^{\mathrm{a}} \pm 0.06$ & $7.40^{\mathrm{a}} \pm 0.06$ & $7.13^{\mathrm{d}} \pm 0.04$ & $7.13^{\mathrm{d}} \pm 0.04$ & $7.13^{\mathrm{d}} \pm 0.04$ & $7.71^{g_{ \pm}} \pm 0.02$ & $7.71^{\mathrm{g}} \pm 0.02$ & $7.71^{\mathrm{g}} \pm 0.02$ \\
\hline
\end{tabular}

N.B.: Different letters indicate significant differences at $0.05 \%$ level of significance. 


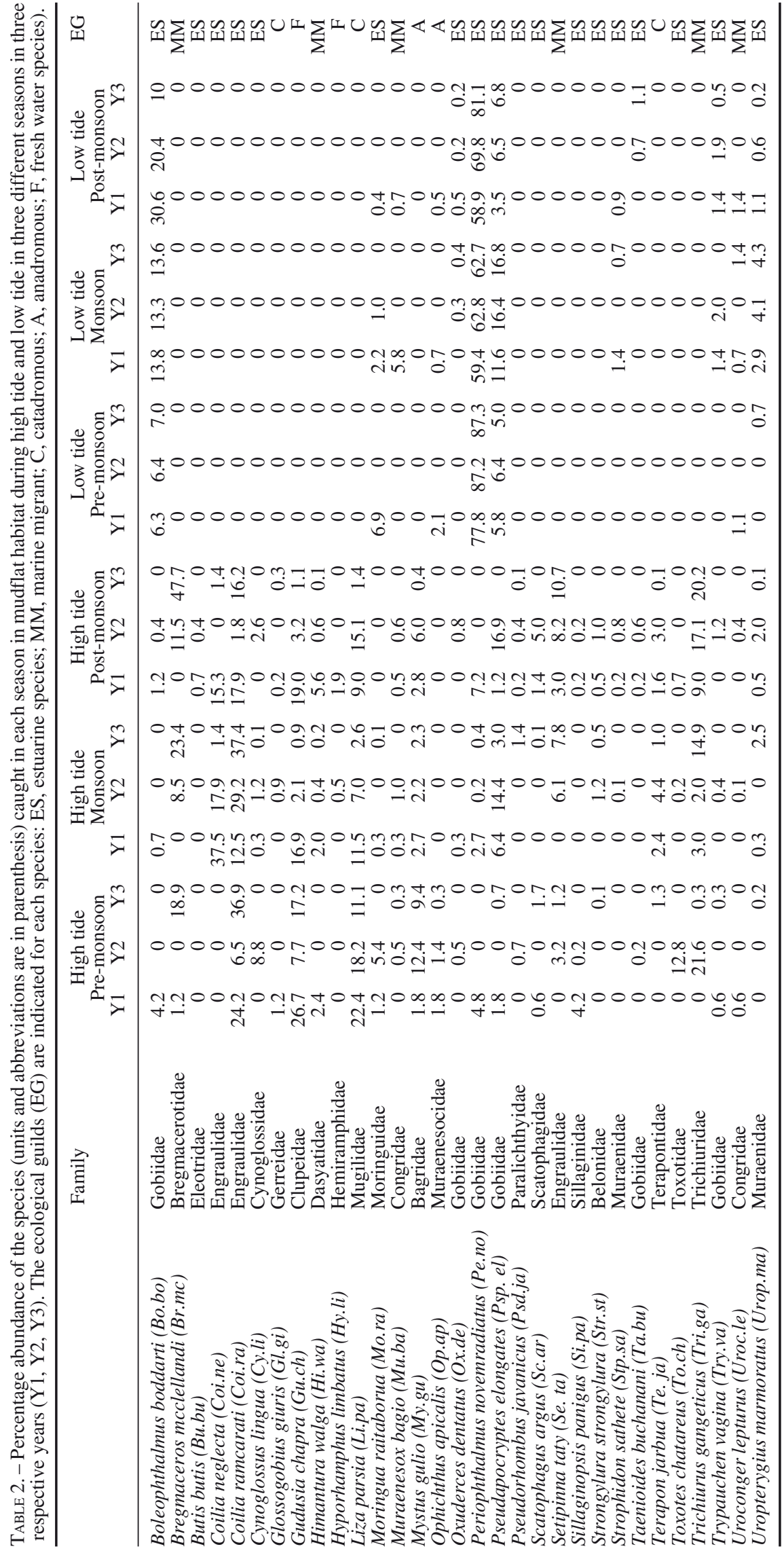

of a year, as well as between years for a particular season.

A total of 4891 individuals were collected, representing 31 species from 22 families and 9 orders (Table 2). Both tidal conditions showed a seasonal pattern in diversity values and ecological guilds. The monsoon and post-monsoon seasons showed significantly higher species diversity $\left(\mathrm{H}^{\prime}\right)$, evenness $(\mathrm{J})$, species richness (S) and lower species dominance (D) $(p=0.000)$ than the pre-monsoon season (Fig. 2) during high-tide sampling. This trend was maintained in all three consecutive years. The diversity indices also varied significantly between years in a particular season. However, the diversity attributes were found to be lower for all seasons during the third year than in the two preceding years. Similarly, during low tide conditions, $\mathrm{H}^{\prime}, \mathrm{S}, \mathrm{J}$ and $\mathrm{D}$ were found to be significantly different $(p=0.000)$ between three respective seasons and monsoon was found to be the most diverse season throughout the study period. Diversity was significantly high $(p=0.000)$ in the first year for all three seasons during lowtide conditions.

Cluster analysis data based on species abundance of three seasons in three years at high tide and low tide illustrated a clear division of fish assemblage into four distinct groups $(55 \%$ Bray-Curtis similarity) (Fig. $3 \mathrm{~A})$. The dendrogram pattern was well supported by nMDS results, which showed considerable distances between four groups (stress value $=0.05$ ) (Fig. $3 \mathrm{~B})$. One group was composed of three seasons of three years at low tide, the second was composed of the monsoon and post-monsoon seasons of the third year at high tide, and the third group was composed of the pre-monsoon season of the first and third year and the monsoon and post-monsoon seasons of the first $(60 \%$ Bray-Curtis similarity) and second year (60\% Bray- 

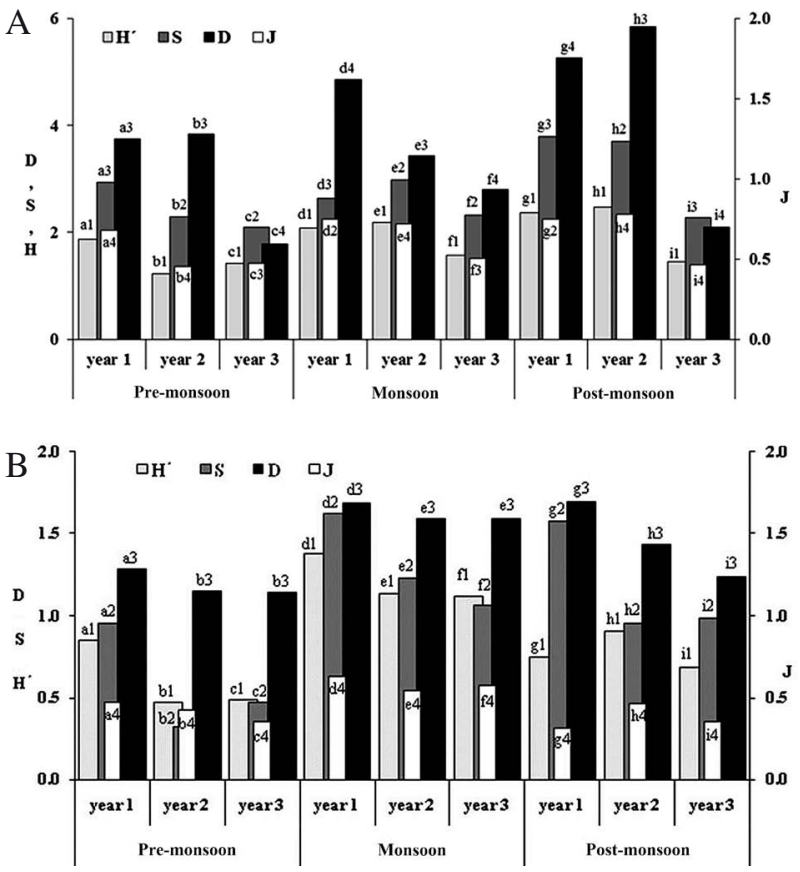

FIG. 2. - Seasonal and inter-annual variation of Shannon-Weiner $\left(\mathrm{H}^{\prime}\right)$, species richness $(\mathrm{S})$, Pielou evenness $(\mathrm{J})$ and species dominance (D) indices for mudflats at high tide (A) and low tide (B). N.B.: Different letters with different numbers indicate significant differences at $0.05 \%$ level of significance.

Curtis similarity) of high tide. The last group was only represented by the pre-monsoon season of the second year at high tide. No significant differences were observed from ANOSIM in the community structure in three seasons and in three years during high-tide and low-tide conditions.

Five ecological guilds were identified during hightide and low-tide conditions when three seasons (premonsoon, monsoon and post-monsoon) of three years were considered. Ecological guilds were analysed by number of species within each guild and 18 estuarine species were found from the 31 species identified in the present study. With regard to the percentage abundance of individuals contributing each ecological guild, oneway ANOVA showed significant differences $(p=0.05)$ between seasons in each year and between years for each season during ebb tide, as shown in Figure 4A. When seasons were compared, ES and MM were found to be the highest in percentage of individuals in the monsoon and post-monsoon seasons, respectively, whereas, $\mathrm{F}$ and $\mathrm{C}$ represented maximum abundance during the pre-monsoon season. A significantly higher percentage abundance of $\mathrm{A}$ was recorded in the pre-monsoon season than in the other seasons in every year. In terms of species contribution for each guild, there were significant differences between seasons of each year and between years of a particular season in high-tide conditions (Fig. 4A). The highest percentage of species within ES and F guilds was recorded in the post-monsoon season, whereas this percentage for A was higher in the pre-monsoon season of all three years studied.
A similar trend was also observed at low tide, though no species of $\mathrm{F}$ and $\mathrm{C}$ species were captured in any seasons of any year and ES contributed the highest percentage of individuals as well as the highest percentage of species throughout the years (Fig. 4B).

The CCA analysis for fish assemblage (based on 432 samples in each tidal phase, including all seasons in the study period) indicated that the variables (abiotic and biotic) explain significantly about $83.5 \%$ (considering a cumulative percentage variance of four axes) and $93.2 \%$ (considering a cumulative percentage variance of four axes) of the fish assemblages during high tide and low tide. Although several axes were determined within the analysis, only axes 1 and 2 were plotted as they accounted for $60.9 \%$ and $81.5 \%$ of the variability explained by four axes for high tide and low tide, respectively.

Considering their vector length $\mathrm{pH}(\mathrm{r}=0.46)$, inorganic phosphate $(\mathrm{r}=-0.40)$, nitrate nitrogen $(\mathrm{r}=-0.64)$, nitrite nitrogen $(\mathrm{r}=-0.50)$ (best correlated with axis 1$)$ and salinity $(\mathrm{r}=0.42,0.43)$ (best correlated with axis 1 and axis 2) were the most important environmental variables influencing the fish assemblages at high tide (Fig. 5A). On the other hand, water temperature $(\mathrm{r}=0.33)$, total dissolved solids $(\mathrm{r}=-0.34)$ (best correlated with axis 1$)$ and salinity $(\mathrm{r}=0.25,-0.20)$ (best correlated with axis 1 and axis 2, respectively) were
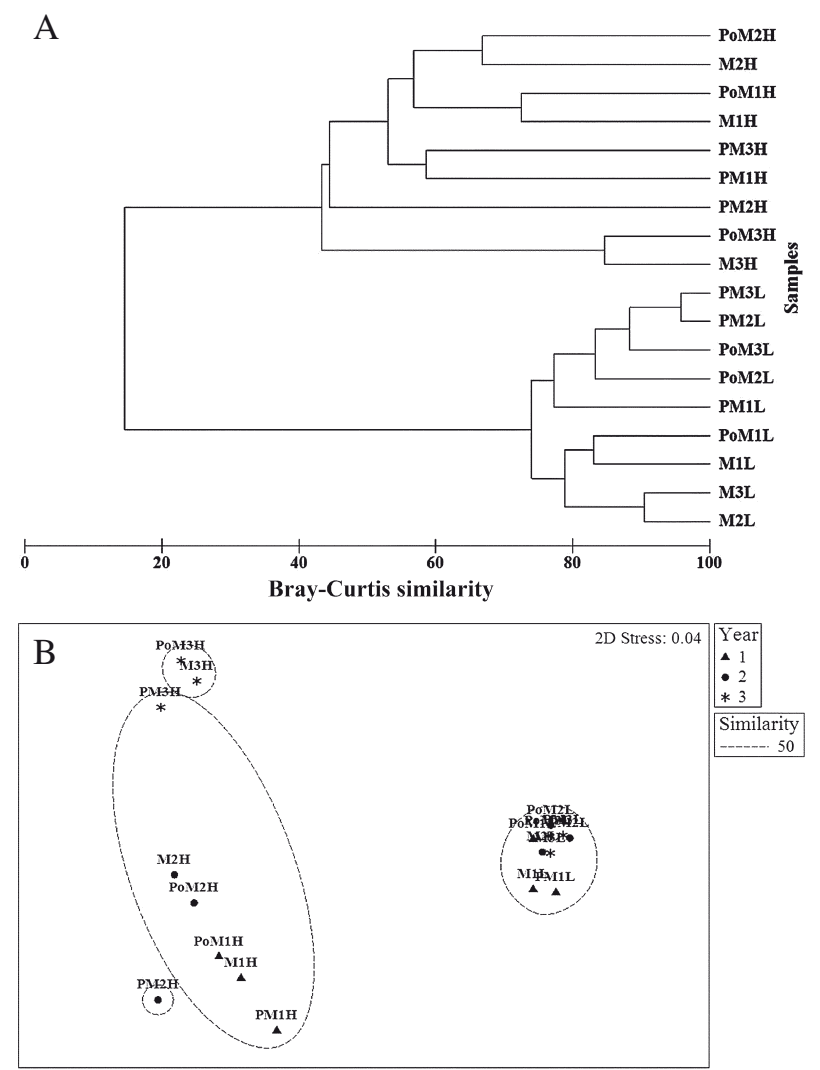

FIG. 3. - Cluster analysis (A) and two-dimensional nMDS plot (B) of the fish assemblages (based on fish abundances) according to Bray-Curtis similarity. Stress value (2D): 0.04. 

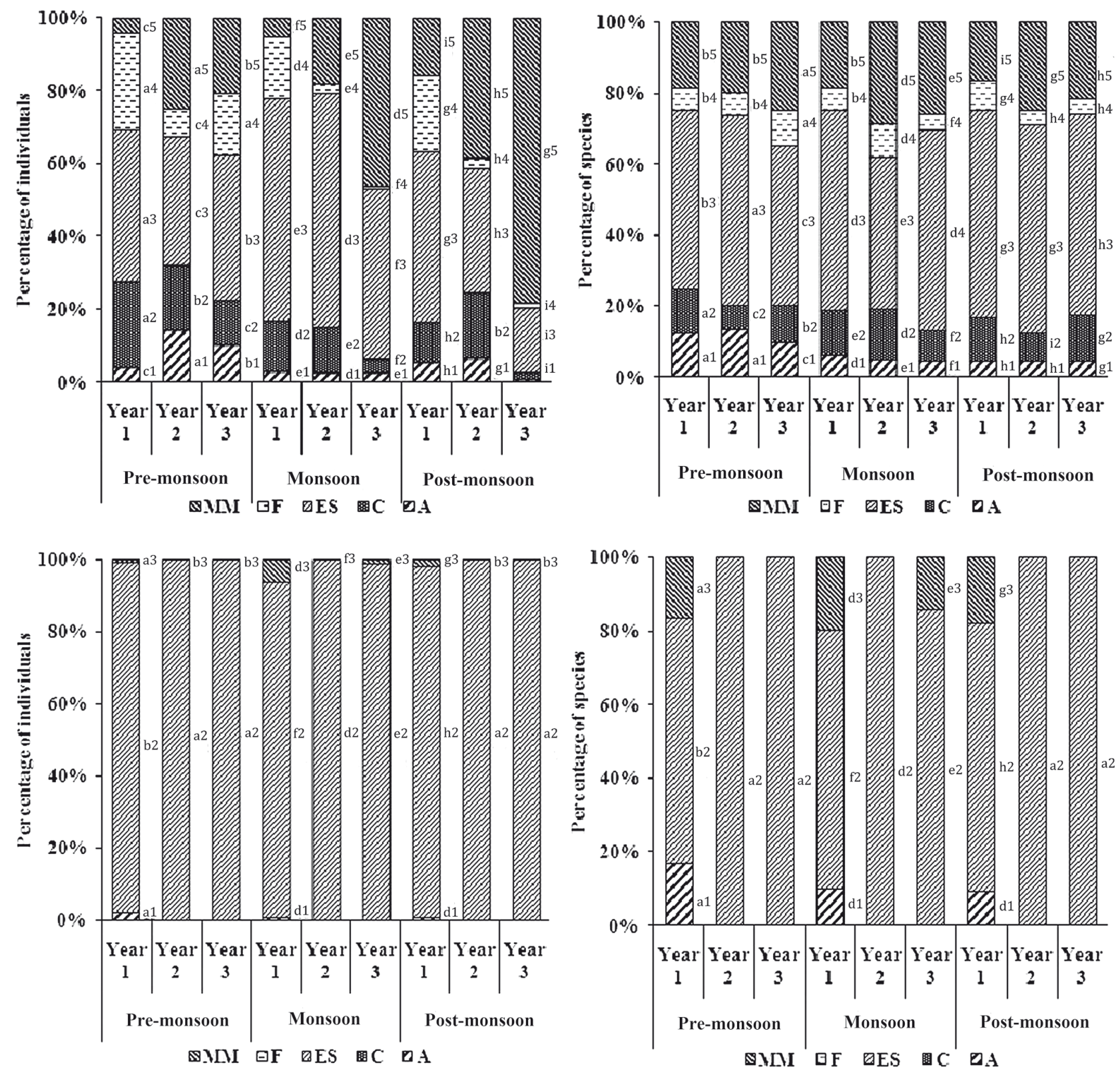

FIG. 4. - Seasonal and inter-annual percentage of ecological guilds for mudflats at high tide (A) and low tide (B) by species composition. Different letters with different numbers indicate significant differences at $0.05 \%$ level of significance.

the most important environmental variables influencing the fish assemblages at low tide (Fig. 5B). During high tide, axis 1 separated the species sensitive to $\mathrm{pH}$ variations (on the right) from those preferring nutrientrich environments (containing nitrate nitrogen, nitrite nitrogen and inorganic phosphate) (on the left), whereas both axes separated the species encountered with higher salinity (in the upper half) from those having lower salinity tolerance (in the lower half). Likewise, during low tide, temperature and total dissolved solids played an important role in classifying species according to axis 1, though axis 2 separated the species having an affinity for salinity (in the upper half) from those sensitive to it (in the lower half) (Fig. 5B).

\section{DISCUSSION}

Estuarine intertidal mudflats are very important in the functioning of estuarine systems and it is generally recognized that they have a disproportionately high productivity when compared to subtidal areas (Elliott and Dewailly 1995). These sheltered shallow waters provide important feeding grounds for juvenile fishes (Haedrich 1983, Able et al. 1990, Costa and Elliott 1991). Little work has been done about the nekton communities that use mudflat habitats. The processes related to the use of these areas by highly mobile individuals like fish are still largely unknown. As the mudflats totally drain during the ebb, the majority of 

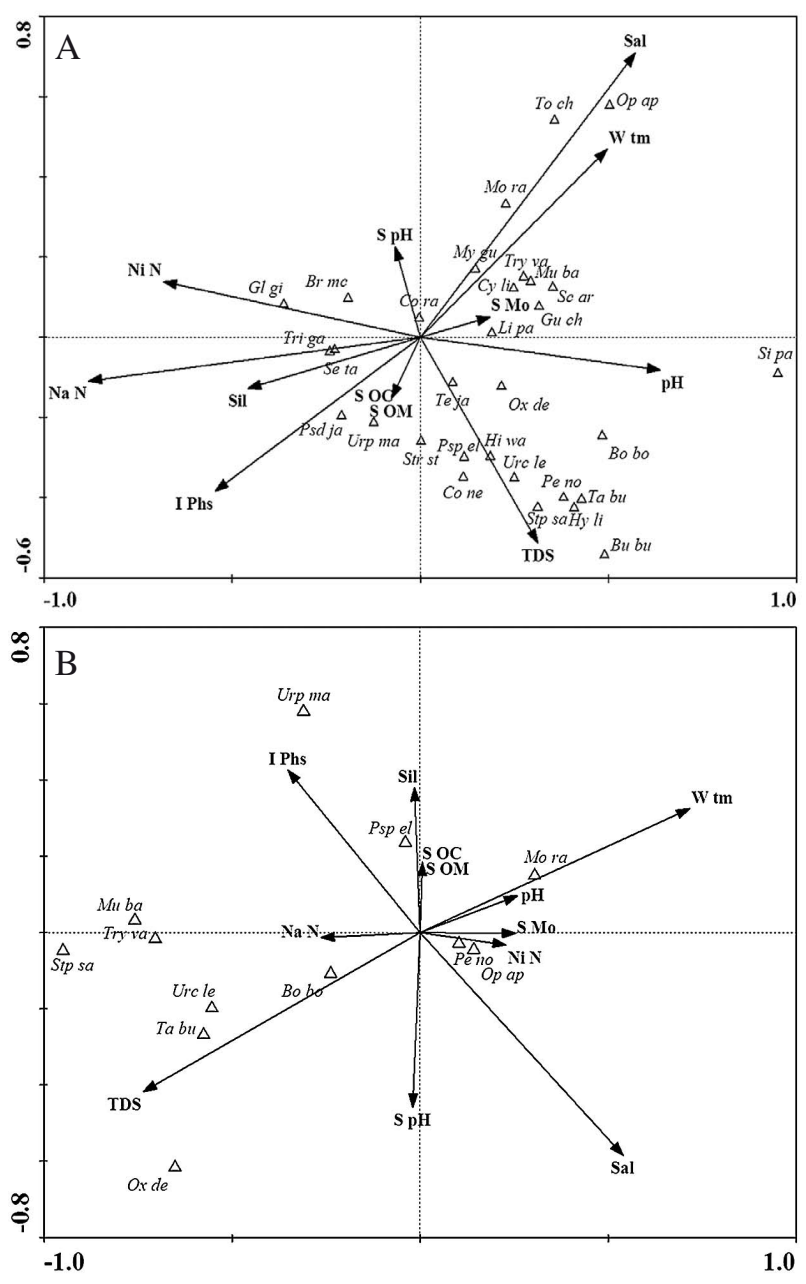

FIG. 5. - Canonical correspondence analysis (CCA) ordination diagram based on species abundances, with abiotic environmental factors represented by vectors in high-tide (A) and low-tide (B) conditions. Variable abbreviations are given in Tables 1 and 2.

the fish species can only migrate when the rising tide floods the intertidal flats (Vinagre et al. 2006).

In the present study 12 species of fishes were recorded in low-tide and 31 species in high-tide conditions. The number of fish species recorded in the studied mudflat during high tide was higher than in other geographical areas, as recorded in previous studies: 22 fish species were recorded on the mudflats of Tagus estuary (Salgado et al. 2004), 17 fish species on an intertidal mudflat of an Australian estuary (Morrison et al. 2002), 20 in an intertidal mudflat of an estuarine system in Japan (Kanou et al. 2005) and 18 in France (Amara and Paul 2003).

The transient nature of many species is a major characteristic of an estuarine fish population that influences diversity. High diversity and species richness is a characteristic feature of subtropical and tropical estuaries of the Indo-Pacific region (Blaber et al. 1989). Emigration and immigration of fish can directly affect the population diversity. In the present study, all diversity indices showed marked seasonal variations, and at high tide the drop in $\mathrm{H}^{\prime}$ during the pre-monsoon season regardless of years (Fig. 2) was directly attributable to the exodus of eight of the studied species (B. butis, $C$. neglecta, $H$. limbatus, $O$. dentatus, $S$. strongyrula, $S$. sathete, T. buchanani and U. marmoratus). The occurrence of mainly three estuarine species, $M$. raitaborus, $S$. panigus and $T$. chatareus, and the immigration of the anadromous species $O$. apicalis occurred during the period. The rise in $\mathrm{H}^{\prime}$ in the monsoon and postmonsoon seasons was primarily a result of the immigration of various marine migrant fish species. The result corroborated the study by Mondal et al. (2010) in two flood plain lakes of India. A similar trend was observed for species richness. On the other hand, during the warm-rainy season (July-September), precipitation and elevated plant production act in concert to contribute allochthonous organic matter (detritus) and nutrients via river discharges and run-off from the lagoon basin, so increasing availability of trophic resources (Castillo-Rivera et al. 1994) leads to higher species diversity. The assemblage groups revealed from the nMDS analysis were clearly separated in the present study according to tidal influence, and to a lesser extent, according to seasonal and inter-annual basis. The high dominance of a few non-commercial species/taxa ( $P$. novemradiatus, Gobiidae), widely distributed in exposed mudflats at low tide during the pre-monsoon season, was also reflected by the low diversity values. In contrast, for some tropical estuarine systems, a higher number of species had been reported in the mudflat habitat than in the adjacent mangrove area (Hindell and Jenkins 2004).

The estuarine fish assemblages were also defined through the use of functional guilds. Functional guild analysis has been proposed as an alternative or addition to traditional community analysis because it can provide more information on the functioning and the internal and hierarchical structure of fish communities (Franco et al. 2006), as well as values for metrics to describe aspects of habitat use by fish (Elliott and Dewailly 1995, Mathieson et al. 2000). Most of the studies using functional guilds aim either to describe the fish assemblage composition of a single estuary or to compare fish assemblages across different estuaries, without taking into account tidal and seasonal differences within a single habitat of the estuary. Fish assemblages in European estuaries are typically dominated by either migrant or straggler marine species, i.e. irregular visitors with no apparent estuarine requirements (Elliott and Dewailly 1995, Thiel and Potter 2001, Maes et al. 2005, Pombo et al. 2007, Franco et al. 2008, Cabral et al. 2012).

The fish assemblage structure of the mudflats of Sundarbans at high tide and low tide consisted of ecological guilds that are quite common in European estuaries (Franco et al. 2008). Estuarine species (43.0\%-58.0\% during high tide and 66.7\%-72.7\% during low tide) were the most important ecological guild of the mudflats of Sundarbans, mainly belonging to 
the orders Clupeiformes and Perciformes. Significant seasonal (except catadromous for the first year) and inter-annual variations in five ecological guilds were observed due to migration of some fishes during high tide. However, the seasonal effect was negligible in the low-tide environment.

At the species level the fish fauna was largely dominated by $P$. novemradiatus at low tide throughout the study tenure, whereas G. chapra, $T$. gangeticus and $C$. ramcarati were dominant in the first year during three respective seasons at high tide. In the second year the two species of Coilia showed maximum dominance throughout the year. However, in the last year in high-tide conditions the fish assemblage was dominated by G. chapra, L. parsia and B. mcclellandi in the pre-monsoon, monsoon and post-monsoon seasons, respectively. The fact that the largest proportion of ES was found in the mudflat habitat suggested that this habitat might play an important role as a suitable feeding ground for several fish species (Nanjo et al. 2008, Chaudhuri et al. 2012). In the last two years of the study period the percentage abundance of MM individuals (e.g. B. mcclellandi, S. taty, T. gangeticus) increased ( $p>0.000)$ compared with the other ecological guilds during high tide, possibly due to the effect of a catastrophic cyclone in the year 2009 (Mukherjee $e t$ al. 2012).

The evident rise in salinity with a concomitant increase in temperature in the later phase of the study period explained the noticeable increase in the marine migrant species during high tide. It also suggests the probable cause of the shift of the fish assemblage composition. However, despite the recognized importance of mudflats as nursery areas (van der Veer et al. 2001, Morrison et al. 2002, Amara and Paul 2003, Vinagre et al. 2006), some controversy exists as to whether or not marine fish species are really dependent on estuaries or just use them opportunistically in order to achieve higher growth rates and a lower exposure to piscivorous predation than is found in other inshore coastal areas (Paterson and Whitfield 2000).

In some geographic areas, sheltered estuarine habitats may offer high densities of prey and other food not encountered in marine areas, and their turbid shallow waters provide protection from predators (McLusky and Elliott 2004). The simultaneous use of estuarine and shallow marine habitats may be a strategy to reduce the intra- and interspecific competition (for food or space), particularly during peak recruitment (Amara et al. 2001). Individual fish may quickly respond to climatic constraints or an increased mortality risk and rapidly shift between coastal and estuarine nursery areas in order to increase their individual state and fitness (Childs et al. 2008).

Understanding the relationship between species distribution and environmental variables allows us to identify the ecological processes that regulate different populations and communities in ecology. However, in addition to all the changes in environmental condi- tions, many species change their habitats according to their ontogeny or seasonal rhythms, which means that relations between different species and their environment or habitat are spatially and seasonally dynamic (Morrison et al. 2002, Kanou et al. 2005).

Several estuarine studies have emphasized the importance of environmental factors affecting seasonal and spatial changes in fish and macrocrustacean assemblage structure (Blaber and Blaber 1980, Rakocinski et al. 1996, Gelwick et al. 2001). The fish assemblage and species composition of the mudflats of Sundarbans is influenced seasonally by a variety of factors. In the present study, nutrients of water, $\mathrm{pH}$ and salinity influenced the assemblage pattern significantly during ebb tide, whereas water temperature, total dissolved solids (TDS), and salinity were the most important environmental variables influencing species richness, abundance and fish assemblage in the intertidal mudflats of the Sundarbans at low tide. The TDS test measures the amount of particles that are dissolved in water. TDS in excessive amounts may be unsuitable for aquatic life. Seasonal analysis revealed that TDS values were low in winter and high in summer and the monsoon season. Similar results were reported by Narain and Chauhan (2002) and Helms et al. (2009). During low tide two estuarine species (T. buchanani and O. dentatus) and one marine migrant species (U. lepturus) showed strong correlation with total dissolved solids. Most of the fishes showed negative correlation with salinity and temperature. Thiel et al. (1995) found temperature to be the best predictor of temporal changes in fish abundance and species composition in the Elbe estuary, Germany. Temperature has been identified as the primary abiotic factor controlling key physiological, biochemical and life-history processes of fish (Beitinger and Fitzpatrick 1979) and has been found to influence the utilization of estuaries by fish worldwide (Blaber 2000, Thiel et al. 1995, Harrison and Whitfield 2006, Nip and Wong 2010). Generally, fish have a thermal preference that optimizes physiological processes.

In the present study salinity was an important factor profoundly influencing the seasonal abundance and distribution of fishes in estuarine environment. The lower salinity was recorded during monsoon was due to heavy rainfall and a large quantity of fresh water inflow. Similar observations were recorded by Kannan and Kannan (1996), Satpathy (1996) and Soundarapandian et al. (2009). The anadromous $O$. apicalis and the estuarine species $T$. chatareus showed an affinity towards salinity during high tide, whereas $S$. panigus may have benefited from a wider $\mathrm{pH}$ tolerance in contrast to $P$. javanicus, G. giuris, $T$. gangeticus and $S$. taty, which preferred a nutrient-rich environment during high-tide conditions.

$\mathrm{pH}$ showed well-marked seasonal variation in the present study, and higher values of $\mathrm{pH}$ were recorded during the pre-monsoon months (average of three years: 7.4). Ananthan et al. (1992) stated that the higher value of $\mathrm{pH}$ in summer was due to the uptake of $\mathrm{CO}_{2}$ 
by photosynthesizing organisms. In the present study, $\mathrm{pH}$ showed associations with fish distributions similar to those of other estuarine systems (Maes et al. 1998, Whitfield 1999). S. panigus showed a positive correlation with $\mathrm{pH}$, whereas the group of fishes G. giuris, $T$. gangeticus, $S$. taty and $P$. javanicus showed affinity for nutrient rich-environments containing nitrate nitrogen, nitrite nitrogen and inorganic phosphate. Dissolved nutrient concentrations were described as the best predictors of species diversity and fish abundance by Winemiller et al. (2000).

Throughout this study, seasonal and inter-annual variations were found in all of the approaches used to analyse fish assemblages: diversity, species compositions and ecological guild distribution. Overall, the low diversity found in the pre-monsoon season was in contrast with the study by Cardoso et al. (2011) in the Portuguese coasts. Estuarine species had higher relative abundances in winter in both high- and low-tide conditions. A similar seasonal pattern was observed for estuarine resident species in the other studies in different European estuaries (Blaber and Blaber 1980, Pombo et al. 2007, França et al. 2008, Selleslagh and Amara 2008). This seasonal pattern allows the use of the mudflats of the Sundarbans to be considered as contributors to the support of coastal fish populations because they contain temporary habitats that provide shelter and feeding grounds to the critical life stages (Cardoso et al. 2011) of many species.

The results of the present study emphasized the importance of this mudflat habitat in the Sundarbans estuary for the nekton communities. Many of the species captured seem to benefit from the advantages of the intertidal habitat, and particularly the high availability of food (Chaudhuri et al. 2012). Further studies about this intertidal mudflat and the communities are crucial in order to understand its structure, dynamics and relation to other estuarine habitats.

\section{ACKNOWLEDGEMENTS}

The authors are thankful to the Head of the Department of Zoology, University of Calcutta for the facilities provided. Financial support from the University Grant Commission, Research Fellowships in Science for Meritorious Students (U.G.C. RFSMS) project is thankfully acknowledged.

\section{REFERENCES}

Able K.W., Matheson R.E., Morse W.W., Fahay M.P., Shepherd G. 1990. Patterns of summer flounder (Paralichthys dentatus) early in the Mid-Atlantic Bight and New Jersey life history estuaries. Fish. Bull. 88: 1-12.

Amara R., Laffargue P., Dewarumez J.M., Maryniak C., Lagardère F., Luczac C. 2001. Feeding ecology and growth of 0-group flatfishes (sole, dab and plaice) at a nursery ground on the southern North Sea. J. Fish Biol. 58: 788-803.

Amara R., Paul C. 2003. Seasonal patterns in the fish and epibenthic crustaceans community of an intertidal zone with particular reference to the population dynamics of plaice and brown shrimp. Estuar. Coast. Shelf Sci. 56: 807-818.
Ananthan G., Ganesan M., Sampathkumar P., Matheven P.M., Kannan L. 1992. Distribution of trace metals in water, sediment and plankton of the Vellar estuary. Seaweed Res. Util. 15: 69-75.

Asha P., Diwakar. S. 2007. Hydrobiology of the inshore waters off Tuticorin in the Gulf. J. Mar. Biol. Ass. India, 49: 7-11.

Banerjee A. 1998. Environment, population and human settlements of Sunderban Delta. 1st Edn. Concept Publishing Company, New Delhi.

Beitinger T.L., Fitzpatrick L.C. 1979. Physiological and ecological correlates of preferred temperature in fish. Am. Zool. 19: 319-329.

Berger W.H., Parker F.L. 1970. Diversity of planktonic foraminifera in deep sea sediments. Science 168: 1345-1347.

Bettencourt A., Ramos L. 2003. Estuários Portugueses. Lisbon: INAG.

Blaber S.J.M. 2000. Tropical estuarine fishes. Ecology, exploitation and conservation. Blackwell Science, Oxford.

Blaber S.J.M., Blaber T.G. 1980. Factors affecting the distribution of juvenile estuarine and inshore fish. J. Fish Biol. 17: 143-162.

Blaber, S.J.M., Brewer D.T., Salinin, J.P. 1989. Species composition and biomasses of fish in different habitats of a tropical northern Australian estuary: their occurrence in the adjoining sea and estuarine dependence. Estuar. Coast. Shelf Sci. 29: 509-531.

Bose S. 2004. The Sunderbans biosphere: a study on uncertainties and impacts in active delta region. In: Proceedings of $2 \mathrm{nd}$. APHW Conference. vol. I. Singapore. pp. 475-483.

Brower J.E., Zar J.H., von Ende C.N. 1998. Field and laboratory methods for general ecology, 4th edn. McGraw-Hill, New York.

Cabral H.N., Fonseca V.F., Gamito R. Goncalves C.I., Costa J.L., Erzini K., Goncalves J., Martins J., Leite L., Andrade J.P., Ramos S., Bordalo A., Amorim E., Neto J.M., Marques J.C., Rebelo J.E., Silva C., Castro N., Almeida P.R., Domingos I., Gordo L.S., Costa M.J. 2012. Ecological quality assessment of transitional waters based on fish assemblages in Portuguese estuaries: the Estuarine Fish Assessment Index (EFAI). Ecol. Indic. 19: 144-153.

Cardoso I., Franca S., Pais M.P., Cancela da Fonseca L., Cabral HN. 2011. Fish assemblages of small estuaries of the Portuguese coast: A functional approach. Estuar. Coast. Shelf Sci. 93: 40-46.

Castillo-Rivera M., Moreno G., Iniestra R. 1994. Spatial, seasonal, and diel variation in abundance of the bay anchovy, Anchoa mitchilli (Teleostei: Engraulidae), in a tropical coastal lagoon of Mexico. Southw. Natur. 39: 263-268.

Castillo-Rivera M., Zarate-Hernandez R., Ortiz-Burgos S., ZavalaHurtado J. 2010. Diel and seasonal variability in the fish community structure of a mud-bottom estuarine habitat in the Gulf of Mexico. Mar. Ecol. 31: 633-642.

Cattrijsse A., Dankwa HR., Mees J. 1997. Nursery function of an estuarine tidal marsh for the brown shrimp Crangon crangon.J. Sea Res. 38: 109-121.

Chaudhuri A., Mukherjee, S. Homechaudhuri, S. 2012. Diet Composition and Digestive Enzymes Activity in Carnivorous Fishes Inhabiting Mudflats of Indian Sundarban Estuaries. Turk. J. Fish. Aquat. Sci. 12: 265-275.

Childs A.R., Cowley P.D., Næsje T.F., Booth A.J., Potts W.M., Thorstad E.B., Økland F. 2008. Estuarine use by spotted grunter Pomadasys commersonnii in a South African estuary, as determined by acoustic telemetry. Afr. J. Mar. Sci. 30: 123-132.

Clarke K.R. 1993. Non-parametric multivariate analyses of changes in community structure. Aust. J. Ecol. 18: 117-143.

Connolly R.M. 1994. A comparison of fish assemblages from seagrass and unvegetated areas of a southern Australian estuary. Aust. J. Mar Fresh. Res. 45: 1033-1044.

Costa M.J., Elliott M. 1991. Fish usage and feeding in two industrialized estuaries - the Tagus, Portugal, and the Forth, Scotland. In: Elliott M., Ducrotoy JP. (eds), Estuaries and coasts: spatial and temporal intercomparisons. Olsen and Olsen, Fredensborg, pp. 289-297.

Damotharan P., Perumal N.V., Perumal P. 2010. Seasonal variation of physico-chemical characteristics of Point Calimere coastal waters (South east coast of India). Middle-East J. Sci. Res. 6: 333-339.

Das J., Das S.N., Sahoo R.K. 1997. Semidiurnal variation of some physico-chemical parameters in the Mahanadi estuary, East Coast of India. Indian J. Mar. Sci. 26: 323-326. 
Day F. 1958. The fishes of India, vol. 1 and 2. William Dawson, London.

Dolbeth M., Cardoso P.G., Ferreira S.M., Verdelhos T., Raffaelli D., Pardal M.A. 2007. Anthropogenic and natural disturbance effects on a macrobenthic estuarine community over a 10-year period. Mar. Pollut. Bull. 54: 576-585.

Elliott M., Dewailly F. 1995. The structure and components of European estuarine fish assemblages. Neth. J. Aquat. Ecol. 29: 397-417.

Elliott M., Hemingway K.L. (eds), 2002. Fishes in estuaries. Blackwell Science Ltd. Oxford.

Franca S., Pardal M.A., Cabral H.N. 2008. Mudflat nekton assemblages in the Tagus (Portugal): distribution and feeding patterns. Sci. Mar. 72: 591-602.

Franco A., Elliott M., Franzoi P., Torricelli P. 2008. Life strategies of fishes in European estuaries: the functional guild approach. Mar. Ecol. Prog. Ser. 354: 219-228.

Franco A., Franzoi P., Malavasi S., Riccato F., Torricelli P., Mainardi D. 2006. Use of shallow water habitats by fish assemblages in a Mediterranean coastal lagoon. Estuar. Coast. Shelf Sci. 66: 67-83.

Gelwick F.P., Akin S., Arrington D.A., Winemiller K.O. 2001. Fish assemblage structure in relation to environmental variation in a Texas Gulf coastal wetland. Estuaries 24: 285-296.

Grasshoff K. 1983. Determination of nitrite, nitrate, oxygen, thiosulphate. In: Grasshoff K., Ehrhardt M., Kremling K. (eds), Methods of seawater analysis. Verlag Chemie Weinheim, New York, pp. 139-142, 143-150, 61-72, 81-84.

Grasshoff K., Erhardt M., Kremling K. 1983. Methods of seawater analysis. 2nd edn. Verlag Chemie Weinheim, New York.

Gray C.A., Chick R.C, McElligott D.J. 1998. Diel changes in assemblages of fishes associated with shallow seagrass and bare sand. Estuar. Coast. Shelf Sci. 46: 849-859.

Griffiths S.P. 2001. Factors influencing fish composition in an Australian intermittently open estuary. Is stability salinitydependent? Estuar. Coast. Shelf Sci. 52: 739-751.

Guelinckx J., Maes J., De Brabandere L., Dehairs F., Ollevier F. 2006. Migration dynamics of clupeoids in the Schelde estuary: a stable isotope approach. Estuar. Coast. Shelf Sci. 66: 612-623.

Guest M.A., Connolly R.M., Loneragan N.R. 2003. Seine nets and beam trawls compared by day and night for sampling fish and crustaceans in shallow seagrass habitat. Fish. Res. 64: 185-196.

Haedrich R.L. 1983. Estuarine fishes. In: Ketchum B. (ed.), Ecosystems of the World: Estuaries and Enclosed Seas. Elsevier, Amsterdam, pp. 183-207.

Halpin P.M. 2000. Habitat use by an intertidal salt-marsh fish: trade-offs between predation and growth. Mar. Ecol. Prog. Ser. 198: 203-214.

Hampel H., Cattrijsse A., Vincx M. 2003. Tidal, diel and semi-lunar changes in the faunal assemblage of an intertidal salt marsh creek. Estuar. Coast. Shelf Sci. 56: 795-805.

Harrison T.D., Whitfield A.K. 2006. Estuarine Typology and the structuring of fish communities in South Africa. Environ. Biol. Fishes 75: 269-293.

Helms B.S., Schoonover J.E., Feminella J.W. 2009. Assessing influences of hydrology, physicochemistry, and habitat on stream fish assemblages across a changing landscape. J. Am. Water Res. Assoc. 45: 157-169.

Hemalatha A. 1996. Studies on benthos from a shrimp farm and in Vellar estuary, Paragipattai. MPhil thesis, Annamalai University, India, $39 \mathrm{pp}$.

Hindell J.S., Jenkins G.P. 2004. Spatial and temporal variability in the assemblage structure of fishes associated with mangroves (Avicennia marina) and intertidal mudflats in temperate Australian embayments. Mar. Biol. 144: 385-395.

Horinouchi M. 2007. Review of the effects of within-patchscale structural complexity on seagrass fishes. J. Exp. Mar. Biol. Ecol. 350: 111-129.

Hyndes G.A., Potter I.C., Platell M.E., Lenanton R.C.J. 1999. Does the composition of the demersal fish assemblages in temperate waters change with depth and undergo seasonal changes? Mar. Biol. 134: 335-352.

Jenkins G.P., Wheatley M.J. 1998. The influence of habitat structure on nearshore fish assemblages in a southern Australian embayment: comparison of shallow seagrass, reef-algal and unvegetated sand habitats, with emphasis on their importance to recruitment. J. Exp. Mar. Biol. Ecol. 221: 147-172.
Kannan R., Kannan L. 1996. Physico-chemical characteristics of sea weed beds of the Palk Bay, Southeast coast of India. Indian J. Mar. Sci. 25: 358-362.

Kanou K., Sano M., Kohno H. 2005. Larval and juvenile fishes occurring with flood tides on an intertidal mudflat in the Tama River estuary, central Japan. Ichthyol. Res. 52: 158-164.

Maes J., Stevens M., Ollevier F. 2005. The composition and community structure of the ichthyofauna of the upper Scheldt estuary: synthesis of a 10-year data collection (1991-2001). J. Appl. Ichthyol. 21: 86-93.

Maes J., van Damme P.A., Taillieu A., Ollevier F. 1998. Fish communities along an oxygen-poor salinity gradient (Zeeschelde Estuary, Belgium). J. Fish Biol. 52: 534-546.

Margalef R. 1957. La teoría de la informaci n en ecología. Mem. $R$. Acad. Ciencias. Barcelona 32: 373-449.

Mathieson S., Cattrijsse A., Costa M.J., Drake P., Elliot M., Gardner J., Marchand J. 2000. Fish assemblages of European tidal marshes: a comparison based on species, families and functional guilds. Mar. Ecol. Prog. Ser. 204: 225-242.

McGarigal K., Cushman S., Stafford S. 2000. Multivariate Statistics for Wildlife and Ecology Research. New York: Springer-Verlag.

McLusky D.S., Elliott M. 2004. The estuarine ecosystem; ecology, threats and management, 3rd edn. OUP, Oxford, $216 \mathrm{pp}$.

Melville A.J., Connolly R.M. 2005. Food webs supporting fish over subtropical mudflats are based on transported organic matter not in situ microalgae. Mar. Biol. 148: 363-371.

Methven D.A., Haedrich R.L., Rose G.A. 2001. The fish assemblage of a Newfoundland estuary: Diel, monthly and annual variation. Estuar. Coast. Shelf Sci. 52: 669-687.

Mondal D.K., Kaviraj A., Saha S. 2010. Water quality parameters and fish biodiversity indices as measures of ecological degradation: A case study in two floodplain lakes of India. J. Water Resource and Protection. 2: 85-92.

Morrison M., Francis M., Hartill B., Parkinson D. 2002. Diurnal and tidal variation in the abundance of the fish fauna of atemperate tidal mudflat. Estuar. Coast. Shelf Sci. 54: 793-807.

Mukherjee S., Chaudhuri A., Sen S., Homechaudhuri S. 2012. Effect of cyclone Aila on estuarine fish assemblages in the Matla River of the Indian Sundarbans. J. Trop. Ecol. 28: 405-415.

Mumby P.J., Skirving W., Strong A.E., Hardy J.T., LeDrew E.F., Hochberg E.J., Stumpf R.P., David L.T. 2004. Remote sensing of coral reefs and their physical environment. Mar. Pollut. Bull. 48: 219-228.

Nagelkerken I., van der Velde G. 2002. Non-estuarine mangroves harbour higher densities of juvenile fish than adjacent shallowwater and coral reef habitats in Curaçao (Netherlands Antilles). Mar. Ecol. Prog. Ser. 245: 191-204.

Nanjo K., Kohno H., Sano M. 2008. Food habits of fishes in the mangrove estuary of Urauchi River, Iriomote Island, southern Japan. Fish. Sci. 74: 1024-1033.

Narain S., Chavhan R. 2000. Water quality status of river complex Yamuna at Panchlnada (Dist. Etawahd, V.P. India) I: An integrated management approach. Poll. Res. 19(3): 357-364.

Nip T.H.M., Wong C.K. 2010. Juvenile Fish Assemblages in Mangrove and Non-Mangrove Soft-Shore Habitats in Eastern Hong Kong. Zool. Stud. 49: 760-778.

Norušis M.J. 2000. SPSS for Windows. Chicago, Illinois: SPSS Inc.

Paterson A.W., Whitfield A.K. 2000. Do shallow-water habitats function as refugia for juvenile fishes? Estuar. Coast. Shelf Sci. 51: 359-364

Pielou E.C. 1969. An introduction to mathematical ecology. New York: Wiley.

Pihl L., Wennhage H. 2002. Structure and diversity of fish assemblages on rocky and soft bottom shores on the Swedish west coast. J. Fish Biol. 61: 148-166.

Pombo L., Rebleo J.E., Elliott M. 2007. The structure, diversity and somatic production of the fish community in an estuarine coastal lagoon, Ria de Aveiro (Portugal). Hydrobiologia 587: 253-268.

Rajasegar M. 2003. Physico-chemical characteristics of the Vellar estuary in relation to shrimp farming. J Environ. Biol. 24: 95-101.

Rakocinski C.F., Lyczkowski-Shultz J., Richardson S.L. 1996. Ichthyoplankton Assemblage structure in Mississippi Sound as revealed by canonical correspondence analysis. Estuar. Coast. and Shelf Sci. 43: 237-257.

Rountree R.A., Able K.W. 1993. Diel variation in decapod crusta- 
cean and fish assemblages in New Jersey marsh creeks. Estuar. Coast. Shelf Sci. 37: 181-201.

Salgado J., Costa M.J., Cabral H., Deegan L. 2004. Comparison of the fish assemblages in tidal salt marsh creeks and in adjoining mudflat areas in the Tejo estuary (Portugal). Cah. Biol. Mar. 45: $213-224$

Satpathy K.K. 1996. Seasonal distribution of nutrients in the coastal waters of Kalpakkam, east coast of India. Indian J. Mar. Sci. 25: $221-224$

Selleslagh J., Amara R. 2007. Temporal variations in abundance and species composition of fish and epibenthic crustaceans of an intertidal zone: environmental factor influence. Cybium 31: 155-162.

Selleslagh J., Amara R. 2008. Environmental factors structuring fish composition and assemblages in a small macrotidal estuary (eastern English Channel). Estuar. Coast. Shelf Sci. 79: 507-517.

Shannon C.E., Wiener W. 1949. The mathematical theory of communication. University of Illinois Press, Urbana, Illinois, $125 \mathrm{pp}$.

Shaw G.E., Shebbeare E.O. 1937. The fishes of North Bengal. J. Roy. Asiatic Soc. Bengal 3: 1-137.

Sogard S.M., Able K.W. 1991. A comparison of eelgrass, sea lettuce macroalgae, and marsh creeks as habitats for epibenthic fishes and decapods. Estuar. Coast. Shelf Sci. 33: 501-519.

Sogard S.M., Powell G.V.N., Hoimquisr J.G. 1989. Utilization by fishes of shallow, seagrass-covered mudbanks in Florida Bay. 2. Diel and tidal patterns. Environ. Biol. Fish. 24: 81-92.

Soundarapandian P., Premkumar T., Dinakaran G.K. 2009. Studies on the physico-chemical characteristic and nutrients in the Uppanar estuary of Cuddalore, South east coast of India. Curr. Res. J. Biol. Sci. 1: 102-105.

Strickland J.D., Parsons T.R. 1972. A practical handbook of seawater analysis. Bull. Fish. Res. Board Can. 167: 310

Talwar P.K., Jhingran A.G. 1991. Inland fishes of India and adja- cent countries, vol. 1 and 2. Oxford and IBH Publishing Co. Pvt. Ltd, New Delhi.

Ter Braak C.J.F. 1988. Partial canonical correspondence analysis. In: Bock H.H. (ed.), Classification and related methods of data analysis. North-Holland, Amsterdam, pp. 551-558.

Thiel R., Potter I.C. 2001. The ichthyofaunal composition of the Elbe Estuary: an analysis in space and time. Mar. Biol. 138: 603-616.

Thiel R., Sepúlveda A., Kafemann R., Nellen W. 1995. Environmental factors as forces structuring the fish community. J. Fish Biol. 46: 47-69.

van der Veer H.W., Dapper R., Witte J. 2001. The nursery function of the intertidal areas in the western Wadden Sea for 0-group sole Solea solea (L). J. Sea Res. 45: 271-279.

Vinagre C., França S., Cabral H.N. 2006. Diel and semi-lunar patterns in the use of an intertidal mudflat by juveniles of Senegal sole, Solea senegalensis. Estuar. Coast. Shelf Sci. 69: 246-254.

Weerts S.P., Cyrus D.P. 2002. Occurrence of young and small-sized fishes in different habitats within a subtropical South African estuary and adjacent harbour. Mar. Freshwat. Res. 53: 447-456.

West R.J., King R.J. 1996. Marine, brackish, and freshwater fish communities in the vegetated and bare shallows of an Australian coastal river. Estuaries 19: 31-41.

Whitfield A.K. 1999. Ichthyofaunal assemblages in estuaries: A South African case study. Rev. Fish Biol. Fisher. 9: 151-186.

Winemiller K.O., Tarim S., Shormann D., Cotner J.B. 2000. Fish assemblage structure in relation to environmental variation among Brazos River Oxbow Lakes. T. Am. Fish. Soc. 129 (2): 451-468.

Zar J.H. 1984. Biostatistical analysis. Prentice-Hall, Englewood Cliffs, N.J.

Scient. ed.: E. Macpherson.

Received October 26, 2012. Accepted February 11, 2013.

Published online March 15, 2013. 